Supporting Information

\title{
Synthesis and Biological Evaluation of a Fluorine-18 Derivative of Dasatinib
}

\begin{abstract}
Darren R. Veach, ${ }^{\dagger} \ddagger$ Mohammad Namavari,,$\S \S$ Nagavarakishore Pillarsetty, $\dagger, \ddagger$ Elmer B. Santos,

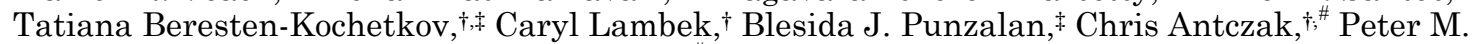

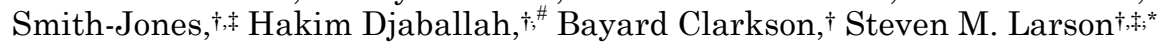

†Department of Molecular Pharmacology and Chemistry, Memorial Sloan-Kettering Cancer Center, New York, NY 10021.

$¥$ Department of Radiology, Memorial Sloan-Kettering Cancer Center, New York, NY 10021.

\# High Throughput Screening Facility, Memorial Sloan-Kettering Cancer Center, New York, NY 10021.

$\S$ Current address: Multimodality Molecular Imaging Lab, Department of Radiology, Stanford University, School of Medicine, Stanford CA 94305.

* To whom correspondence should be addressed: Memorial Sloan-Kettering Cancer Center, Box 77, 1275 York Avenue, New York, NY 10021.Phone: (212)639-7373.E-mail: LarsonS@mskcc.org
\end{abstract}

\section{Table of Contents}

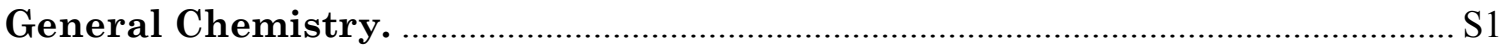

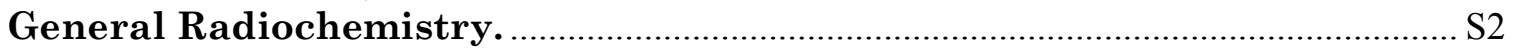

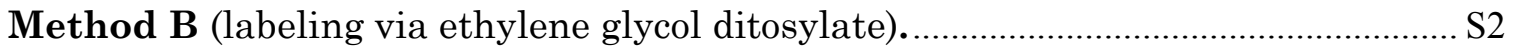

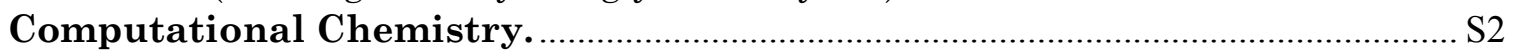

Analytical HPLC chromatogram of [18 F]

Octanol/Water Partition Coefficient Determination. ....................................... S3

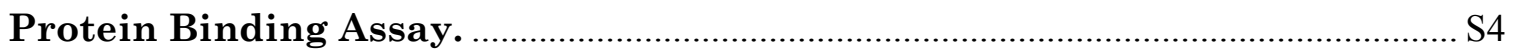

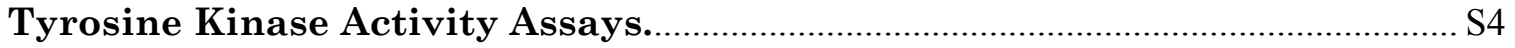

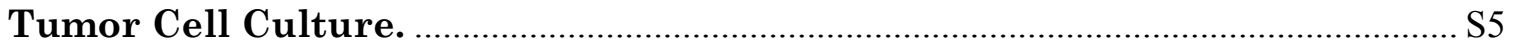

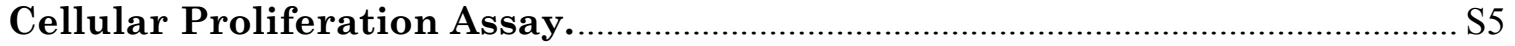

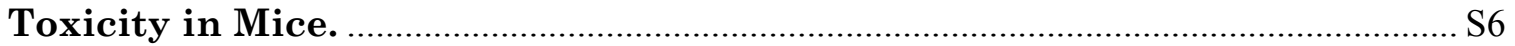

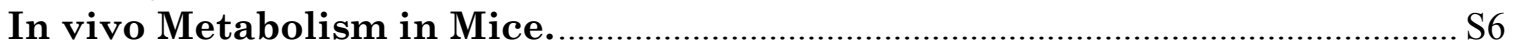

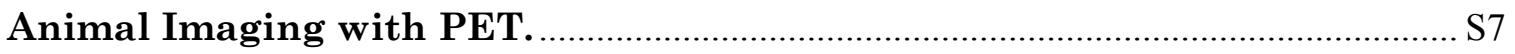

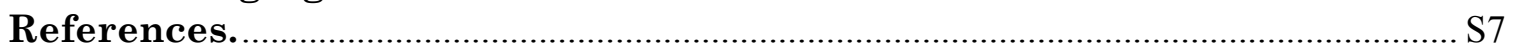

\section{General Chemistry.}

All chemicals and solvents were obtained from Sigma-Aldrich (Milwaukee, WI) or Fisher Scientific (Pittsburgh, PA) and used without further purification. ${ }^{1}{ }^{1} \mathrm{H},{ }^{13} \mathrm{C}$, and ${ }^{19} \mathrm{~F}$ NMR spectra were recorded on a Bruker AMX-400 at 400, 100 and $376 \mathrm{MHz}$, respectively or a Bruker AVANCE II 500 at 500, 125 or $470 \mathrm{MHz}$, respectively. Chemical shifts (ס) are determined relative to $\mathrm{CDCl}_{3}$ (referenced to $7.27 \mathrm{ppm}(\delta)$ for ${ }^{1} \mathrm{H}-\mathrm{NMR}$ and $77.0 \mathrm{ppm}$ for ${ }^{13} \mathrm{C}$ NMR) or DMSO- $d_{6}$ (referenced to $2.49 \mathrm{ppm}(\delta)$ for ${ }^{1} \mathrm{H}-\mathrm{NMR}$ and $39.5 \mathrm{ppm}$ for ${ }^{13} \mathrm{C}-\mathrm{NMR}$ ). The internal reference for ${ }^{19} \mathrm{~F}-\mathrm{NMR}$ was $\mathrm{CFCl}_{3}(0.0 \mathrm{ppm}(\delta))$. Coupling constants $(J)$ are given in Hertz and spectral splitting patterns are designated as singlet (s), doublet (d), triplet (t), quadruplet (q), multiplet or overlapped (m), and broad (br). Low resolution mass spectra (ionspray, a variation of electrospray) were acquired on a Perkin-Elmer Sciex API 100 spectrometer. HRMS service was obtained from the Mass Spectrometry Lab at UIUC and acquired on a Micromass $70-\mathrm{SE}-4 \mathrm{~F}$ spectrometer using $\mathrm{FAB}^{+}$ionization. HPLC was performed on a Jasco (Easton, MD) system comprised of a PU-2089plus pump, UV-2075plus UV/VIS detector, LCNetII/ADC data acquisition system and Windows PC running EZChrom Elite v3.1.4 software. Flash chromatography was performed using Merck silica gel 60 (mesh 
size 230-400 ASTM) or using an Isco (Lincoln, NE) CombiFlash Companion or SQ16x flash chromatography system with RediSep columns (normal phase silica gel (mesh size 230-400 ASTM) and Fisher Optima ${ }^{\mathrm{TM}}$ grade solvents. Microwave reactions were performed in a CEM Discover microwave reaction system (Matthews, NC). Thin-layer chromatography (TLC) was performed on E. Merck (Darmstadt, Germany) silica gel F-254 aluminum-backed plates with visualization under UV $(254 \mathrm{~nm})$ and by staining with potassium permanganate or ceric ammonium molybdate. Molecular modeling was performed using SYBYL 7.1 (Tripos Inc., St. Louis, MO) on an Intel Xeon PC workstation running RedHat Enterprise Linux 3.

\section{General Radiochemistry.}

All HPLC solvents were filtered $(0.45 \mu \mathrm{m}$, nylon, Alltech) prior to use. Water (ultrapure, ion-free) was obtained from a Millipore Alpha-Q Ultra-pure water system. Sep-Pak® cartridges were obtained from Waters Corporation (Milford, MA). Radio-TLC was performed on silica gel plates $(5 \times 20 \mathrm{~cm} ; 250 \mu \mathrm{m}$ thickness; Aldrich, Milwaukee, WI) and analyzed with a BioScan AR-2000 Imaging Scanner (BioScan Inc., Washington D.C.) HPLC was performed using a Shimadzu (Columbia, MD) system composed of a C-18 reversed-phase column (Phenominex Luna analytical $4.6 \times 250 \mathrm{~mm}$ or semi-prep $10 \times 250 \mathrm{~mm}, 5 \mu, 1.0$ or $4.0 \mathrm{~mL} / \mathrm{min}$, $50 \mathrm{mM} \mathrm{pH} 5.5 \mathrm{NaOAc} / \mathrm{CH}_{3} \mathrm{CN}$ ), two LC-10AT pumps, an SPD-M10AVP photodiode array detector and a BioScan Flow Count radiodetector using a $25 \times 25 \mathrm{~mm} \mathrm{NaI(Tl)}$ crystal. Radioactivity was assayed using a Capintec CRC-15R dose calibrator (Ramsey, NJ).

No-carrier-added $\left[{ }^{18} \mathrm{~F}\right]$ fluoride ion was produced by the ${ }^{18} \mathrm{O}(\mathrm{p}, \mathrm{n})^{18} \mathrm{~F}$ nuclear reaction by bombardment of an enriched $\left[{ }^{18} \mathrm{O}\right] \mathrm{H}_{2} \mathrm{O}$ target with $11 \mathrm{MeV}$ protons using an EBCO-TR19 cyclotron. The ${ }^{18} \mathrm{~F}$ fluoride ion was trapped on an Accell ${ }^{\mathrm{TM}}$ Plus QMA ion-exchange cartridge (Waters).

Method B (labeling via ethylene glycol ditosylate).

The QMA cartridge containing cyclotron-produced $\left[{ }^{18} \mathrm{~F}\right]$ fluoride ion was eluted with a solution containing $420 \mu \mathrm{L}$ of $\mathrm{H}_{2} \mathrm{O}$ and $120 \mu \mathrm{L}$ of $0.25 \mathrm{M} \mathrm{K}_{2} \mathrm{CO}_{3}(20 \mu \mathrm{mol})$ into a $5 \mathrm{~mL}$ Reactivial containing $10 \mathrm{mg}(2.7 \mathrm{\mu mol})$ of Kryptofix [2.2.2] in $0.5 \mathrm{~mL} \mathrm{CH} 3 \mathrm{CN}$. Water was removed azeotropically with $\mathrm{CH}_{3} \mathrm{CN}(3 \times 0.5 \mathrm{~mL})$ at $105-110{ }^{\circ} \mathrm{C}$. To the anhydrous $\left[{ }^{18} \mathrm{~F}\right] \mathrm{KF} / \mathrm{K}_{2} \mathrm{CO}_{3}$ complexed with Kryptofix was added a solution of ethylene glycol ditosylate $(2.0 \mathrm{mg}, 5.4$ $\mu \mathrm{mol})$ in $\mathrm{CH}_{3} \mathrm{CN}(100 \mu \mathrm{L})$ and heated (sealed) in an oil bath at $110^{\circ} \mathrm{C}$ for $10 \mathrm{~min} .{ }^{2}$ The reaction mixture was cooled to room temp. and treated with a solution of $5.5 \mathrm{mg}$ of piperazine precursor 4 in $100 \mu \mathrm{L}$ of DMSO. The mixture was heated at $160^{\circ} \mathrm{C}$ for $30 \mathrm{~min}$, cooled, and passed through a C-18 Sep-Pak column activated previously with $8 \mathrm{~mL}$ of $\mathrm{MeOH}$ followed by $10 \mathrm{~mL}$ of DI water. The Sep-Pak was washed with water $(2 \times 6 \mathrm{~mL})$ and $\left[{ }^{18} \mathrm{~F}\right]-5$ eluted with $\mathrm{CH}_{3} \mathrm{CN}(1.2 \mathrm{~mL})$. The Sep-Pak was washed with $0.8 \mathrm{~mL}$ of water and the combined $\left[{ }^{18} \mathrm{~F}\right]$ solution purified and formulated as in method A. Total time of radiosynthesis was $120 \pm 10$ minutes from EOB. The decay-corrected radiochemical yield was $23 \pm 5 \%(\mathrm{n}=3)$ over two steps based on starting $\left[{ }^{18} \mathrm{~F}\right]$-fluoride. The specific activity was $3-6 \mathrm{mCi} / \mu \mathrm{mol}(\mathrm{n}=3)$.

\section{Computational Chemistry.}

Molecular modeling and graphics renderings were performed using the SYBYL 7.1 (Tripos Associates Inc., St. Louis, MO) software package on an Intel Xeon PC workstation running RedHat Enterprise Linux 3.

The Abl kinase:PD166326 kinase inhibitor cocrystal structure ${ }^{3}$ was used as the initial model. This file can be obtained from the protein databank (coordinate file 1OPK, www.rcsb.org). A more appropriate starting structure would be the Abl:dasatinib cocrystal structure reported by Tokarski, et al., ${ }^{4}$ but at the time we began this work, the coordinate file $2 \mathrm{GQG}$ had not been released on the RCSB. The atom types for the inhibitor were corrected, hydrogen atoms were added to the protein and the $\mathrm{C}$ and $\mathrm{N}$ endgroups were fixed using the SYBYL/BIOPOLYMER module. Protein and inhibitor atomic charges were calculated using MMFF94 force field. The complex was minimized using the SYBYL gradient convergence 
method with an MMFF94s force field and $0.05 \mathrm{kcal} / \mathrm{mol} \cdot \AA \mathrm{rms}$ gradient as the convergence criterion. All heavy atoms (inherent to the crystal structure) were constrained in an aggregate during minimization. To create the Abl kinase:Compound $\mathbf{5}$ model, the inhibitor in the AblK:PD166326 cocrystal structure was replaced with compound $\mathbf{5}$ in an orientation that preserves the H-bond donor acceptor pair at Met318 and directs the fluoroethylpiperazinyl moiety out into solvent-exposed area (Figure S2). The inhibitor atoms were allowed to move freely for minimization. Conformational analysis run on the ligand showed that the fluoroethyl sidechain has considerable freedom of motion. Several lowest energy conformers of the terminal fluoroethyl group were found and minimized, but ultimately showed negligible differences in energy.

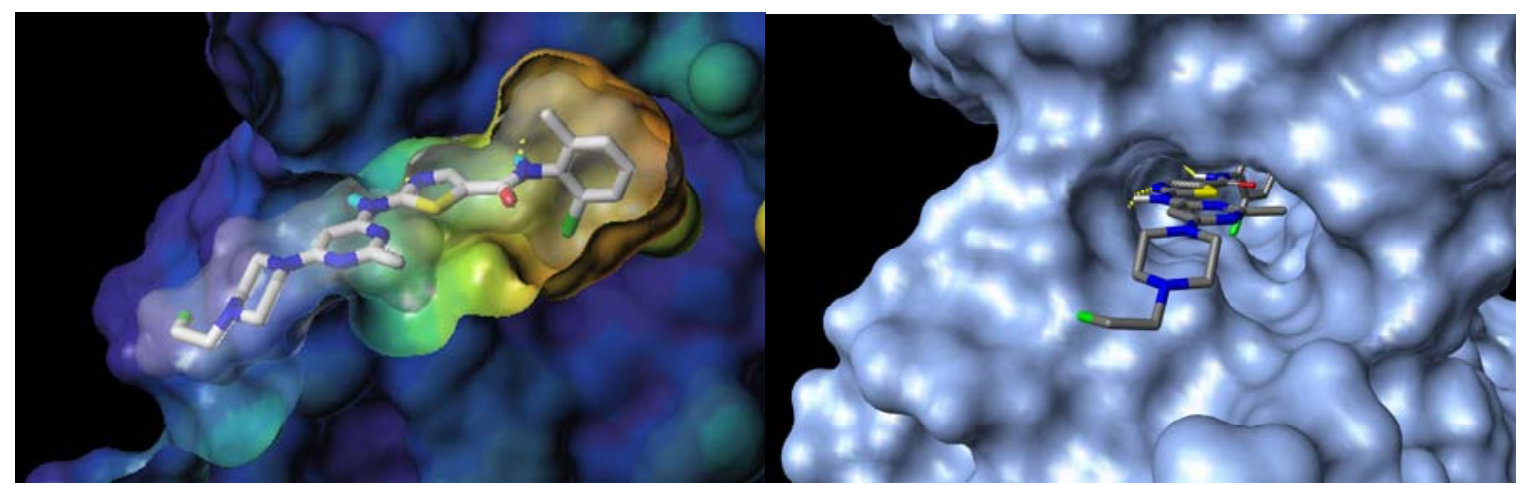

Figure S2. Cavity-depth (left) and Connolly (right) surface renderings of $\mathbf{5}$ docked into Abl kinase domain.

Analytical HPLC chromatogram of [18F]-5.
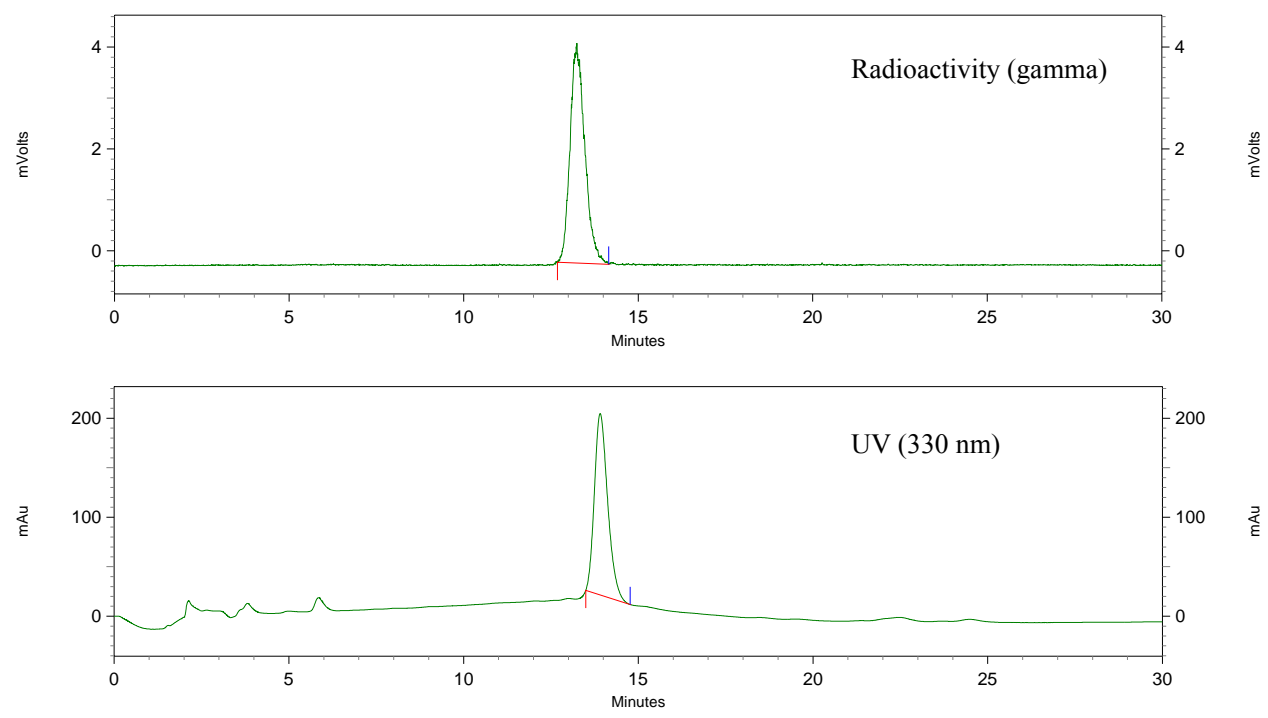

Figure S2. HPLC chromatogram showing coelution of $\left[{ }^{18} \mathrm{~F}\right]-5$ with co-injected nonradioactive reference ${ }^{19} \mathrm{~F}$ compound 5. Phenominex Luna $\mathrm{C}_{18} 4.6 \times 250 \mathrm{~mm}, 5 \mu$, isocratic $60 \% \mathrm{NaOAc} / 40 \% \mathrm{CH}_{3} \mathrm{CN}, 1.0 \mathrm{~mL} / \mathrm{min}$. ( $\Delta=0.4 \mathrm{~min}$ between detectors).

\section{Octanol/Water Partition Coefficient Determination.}

Octanol/water partition coefficients are determined for each radiotracer by shaking $370 \mathrm{KBq}(10 \mu \mathrm{Ci})$ of each radioligand with $10 \mathrm{~mL}$ of $n$-octanol and $10 \mathrm{~mL}$ of water for 2 hours. Octanol and water are presaturated for at least 24 hours prior to use. The two layers are separated and spun in a centrifuge at $1000 \mathrm{~g}$ for 20 minutes. $1 \mathrm{~mL}$ samples are recovered 
with a syringe with a 25 gauge needle from each solvent and counted in a gamma counter. The samples of both layers are also analyzed for impurities by HPLC and the partition coefficient determined.

\section{Protein Binding Assay.}

Protein binding of the radiotracers are determined adding $37 \mathrm{kBq}(1 \mu \mathrm{Ci})$ of each radioligand to samples of $1 \%$ bovine serum albumin and $1 \mathrm{~mL}$ of fresh human serum. The protein is precipitated by adding $1 \mathrm{~mL}$ of ice cold $20 \%$ trichloroacetic acid and the suspension centrifuged and washing with $1 \mathrm{~mL}$ of $20 \%$ ice cold trichloroacetic acid. The protein pellets and supernatants are counted in a gamma counter to determine the protein binding of the radioligands.

\section{Tyrosine Kinase Activity Assays.}

$\mathrm{Abl}$ and Src kinase activity was measured according to Trentham ${ }^{5}$ with some modifications. For Abl, the reaction was in $25 \mathrm{mM}$ Hepes buffer $\mathrm{pH} 7.5,10 \mathrm{mM} \mathrm{MgCl}, 2 \mathrm{mM}$ DTT, $20 \mathrm{mM}$ B-glycerol phosphate, $0.1 \quad \mathrm{mM} \quad \mathrm{Na}_{3} \mathrm{VO}_{4}, \quad 120 \mu \mathrm{M}$ B-NADH, $500 \mu \mathrm{M}$ phosphoenolpyruvate, and including $3.1 \mathrm{\mu g} / \mathrm{ml} \mathrm{L-lactic} \mathrm{dehydrogenase,} 6.67 \mathrm{\mu g} / \mathrm{ml}$ pyruvate kinase, $0.005 \%$ Tween 80, 1\% DMSO, $5 \mathrm{nM}$ Abl kinase (Invitrogen), $30 \mu \mathrm{M}$ peptide substrate (EAIYAAPFAKKK) $\left(\sim 1 \times \mathrm{K}_{\mathrm{m}}\right)$, and $200 \mu \mathrm{M}$ ATP $\left(\sim 10 \times \mathrm{K}_{\mathrm{m}}\right)$. For Src, the same reaction conditions were used except for the following: $10 \mathrm{mM} \mathrm{MnCl}$ (instead of $\mathrm{MgCl}_{2}$ ), $20 \mathrm{nM}$ Src kinase, $300 \mu \mathrm{M}$ KVEKIGEGTYGVVYK-OH peptide $(\sim 1 \times \mathrm{Km}), 200 \mu \mathrm{M}$ ATP $\left(\sim 3 \times \mathrm{K}_{\mathrm{m}}\right)$. Kinase was preincubated with inhibitor at $37^{\circ} \mathrm{C}$ for 10 min prior to starting the reaction upon addition of ATP; Assay was carried out in 384 well clear plates (Corning) and absorbance was measured on SpectraMax plate reader (Molecular Devices). Reaction rates were plotted against inhibitor concentration and fitted using SigmaPlot 9.0 (Systat Software Inc.).

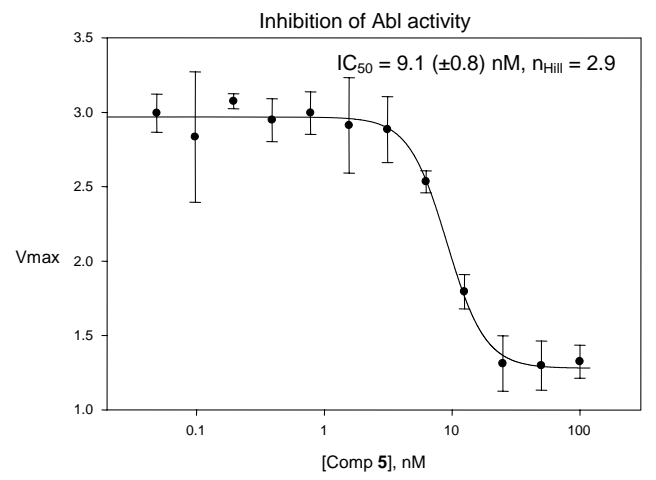

Figure S3. Representative data: determination of $\mathrm{IC}_{50}$ of $\mathrm{Abl}$ kinase activity.

In addition to the rigorous $\mathrm{IC}_{50}$ determinations in $\mathrm{Abl}$ and Src kinase above, a set of 21 tyrosine kinases were evaluated using Carna Biosciences' (Kobe, Japan) QuickScout ${ }^{\mathrm{TM}}$ service to measure kinase activity inhibition by compound $\mathbf{5}$ at $10 \mathrm{nM}$. Staurosporine was used as a control / benchmark inhibitor. Literature $\mathrm{K}_{d}$ values for dasatinib are included for comparison. An ELISA-based assay was used in which the phosphorylation of an oligopeptide substrate was detected by an HRP-conjugated anti-p-Tyr (PY20) probe. The concentration of ATP was at the approximate $\mathrm{K}_{\mathrm{m}}$ of each kinase $(0.5-100 \mu \mathrm{M})$. The data appears in Table $\mathrm{S} 1$, below. Negative values, particularly for TIE2, are not readily explainable, but should be interpreted as an enhancement of substrate phosphorylation. 
Table S1. Inhibitory activity of Compound $\mathbf{5}$ and staurosporine against 21 tyrosine kinases at $10 \mathrm{nM}$.

\begin{tabular}{|c|c|c|c|c|}
\hline \multirow[b]{2}{*}{ Kinase } & \multicolumn{2}{|c|}{$\%$ Inhibition of Kinase Activity } & \multirow[b]{2}{*}{$\begin{array}{c}\text { Staurosporine } \\
\text { conc. (nM) }\end{array}$} & \multirow{2}{*}{$\begin{array}{c}\text { Dasatinib }^{6} \\
\mathrm{~K}_{d}(\mathrm{nM})\end{array}$} \\
\hline & $\begin{array}{c}\text { Compound } \mathbf{5} \\
(10 \mathrm{nM})\end{array}$ & Staurosporine & & \\
\hline $\mathrm{ABL}$ & 99.4 & 87.2 & (1000) & 0.50 \\
\hline ACK & 83.1 & 96.4 & (30) & 6.0 \\
\hline TYRO3 & 23.1 & 95.3 & (1000) & -- \\
\hline CSK & 95.2 & 89.3 & $(300)$ & 1.0 \\
\hline EGFR & 27.2 & 82.4 & (10000) & 100 \\
\hline EphA2 & 98.1 & 92.6 & (10000) & 0.80 \\
\hline EphB4 & 97.0 & 94.1 & (10000) & 0.30 \\
\hline FAK & -18.3 & 81.7 & (100) & -- \\
\hline FGFR1 & 20.4 & 86.5 & $(100)$ & 4000 \\
\hline IGF1R & 5.9 & 96.9 & (3000) & $>10000$ \\
\hline JAK3 & 16.0 & 95.3 & (3) & -- \\
\hline MET & 7.2 & 90.0 & $(300)$ & -- \\
\hline FLT3 & 0.3 & 96.4 & (3) & 5000 \\
\hline KIT & 98.7 & 96.7 & (10) & 0.60 \\
\hline PDGFRa & 86.0 & 88.4 & (3) & 0.40 \\
\hline SRC & 97.5 & 89.8 & (3000) & 0.20 \\
\hline SYK & 4.5 & 90.2 & (30) & 3000 \\
\hline TEC & 98.1 & 92.5 & $(300)$ & -- \\
\hline TIE2 & -51.7 & 90.9 & $(300)$ & $>10000$ \\
\hline TRKA & -0.9 & 94.0 & (3) & $>10000$ \\
\hline KDR & -5.6 & 91.8 & $(300)$ & 3000 \\
\hline
\end{tabular}

\section{Tumor Cell Culture.}

The immortalized human hematopoietic Philadelphia chromosome-positive cytokine

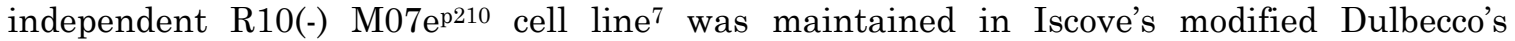
medium (Life Technologies, Inc., Grand Island, NY) containing 10\% FCS (Hyclone, Logan, UT). The parental M07e megakaryoblastic cell line was a kind gift of Brian Druker and was maintained in the presence of $50 \mathrm{ng} / \mathrm{mL}$ kit ligand (SCF) as described previously.7, 8 K562 was obtained from the ATCC. K562 was maintained in suspension in 90\% RPMI 1640 medium supplemented with 10\% FBS, $2 \mathrm{mM}$ L-glutamine, $10 \mathrm{mM}$ HEPES, $1 \mathrm{mM}$ sodium pyruvate, $1.5 \mathrm{~g} / \mathrm{L}$ sodium bicarbonate, $4.5 \mathrm{~g} / \mathrm{L}$ L-glucose, $10 \% \mathrm{FBS}, 100 \mathrm{IU} / \mathrm{mL}$ penicillin and $100 \mu \mathrm{g} / \mathrm{ml}$ streptomycin. Tumor cell cultures were maintained in a humidified atmosphere with $5 \% \mathrm{CO}_{2}$ at $37^{\circ} \mathrm{C}$ (NuAire).

\section{Cellular Proliferation Assay.}

Cell growth was determined by a $\left[{ }^{3} \mathrm{H}\right]$ thymidine uptake assay. Cells $\left(10^{4}\right.$ cells/well) were cultured in 96-well, round-bottomed plates (Fisher Scientific) with diluted DMSO (control) or with varying concentrations of dasatinib or fluorinated derivative $\mathbf{5}$ that were resuspended in DMSO for $48 \mathrm{~h}$ at $37^{\circ} \mathrm{C}$. $\left[{ }^{3} \mathrm{H}\right]$ Thymidine was added at a concentration of 1 $\mu \mathrm{Ci} /$ well, and cells were incubated for an additional $18 \mathrm{~h}$. Cells were harvested with the Unifilter system, scintillation fluid ( $25 \mu \mathrm{l} /$ well) was added to each well, and $\left[{ }^{3} \mathrm{H}\right]$ thymidine incorporation was determined on a Packard Scintillation Counter. Data points for all assays were obtained in triplicate, and background incorporation from cell-free wells was determined and subtracted from all data points. The data was analyzed using a non-linear regression fit to a sigmoidal dose-response curve using Prism 4 (GraphPad Software, Inc). 

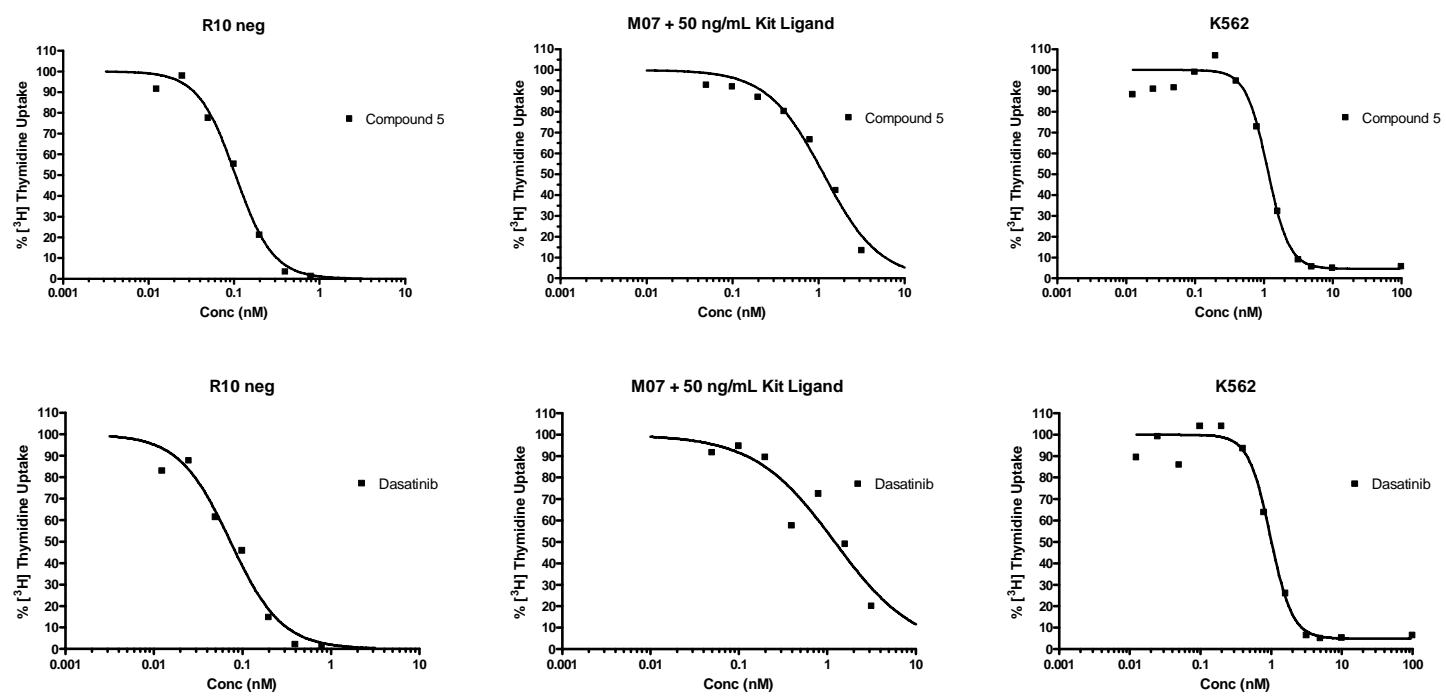

Figure S3. Inhibition of cellular proliferation of M07e/p210 bcr-abl (R10 neg), M07e, and K562 cell lines with fluorinated analog $\mathbf{5}$ versus dasatinib.

\section{Toxicity in Mice.}

Mice were injected i.v. with unlabeled $\left.{ }^{19} \mathrm{~F}\right)$ reference compound $\mathbf{5}$ in the tail vein and sacrificed using carbon dioxide at 30,60 and 120 min post injection. Each group contained three mice. A total of 24 eight-week-old B6D2F1 mice (average initial weight was $22.9 \mathrm{~g}$ for male mice and $18.5 \mathrm{~g}$ for female mice) were used in the acute toxicity study. There were five males and five females in either control or treatment group. The treatment group received one dose of compound $\mathbf{5}(0.1 \mathrm{mg} / \mathrm{kg})$ intravenously through tail vein injection and the control group received the same amount of vehicle (85\% beta-hydroxypropyl cyclodextrine, $5 \%$ DMSO, 10\% EtOH). All animals were observed for 14 days following treatment. Observation showed no apparent anemia, no weight loss, no agitation, no tachypnea, no GI disturbances and no apparent neurological dysfunction in all mice. In both the control and treatment groups, male mice gained on average $1.8 \mathrm{~g}$ in body weight and females gained on average 0.5 g. Mice were sent for pathology, including complete blood cell count, complete chemistry panel and complete necropsy. Two intact male mice and two intact female mice were also sent and used as references. Results showed no significant abnormalities in any control or treated mouse compared with intact mice. There was no evidence of drug-induced or vehicle induced organ toxicities. In conclusion, fluoro derivative 5, administered at $0.1 \mathrm{mg} / \mathrm{Kg}$ intravenously, is safe and nontoxic in B6D2F1 mice.

\section{In vivo Metabolism in Mice.}

Mice were injected i.v. with $\left[{ }^{18} \mathrm{~F}\right]-5$ in the tail vein and sacrificed using carbon dioxide at 30 , 60 and 120 min post injection. Each group contained three mice. Immediately after sacrifice, about $0.5 \mathrm{ml}$ of blood was collected by cardiac puncture and deposited in a $1.5 \mathrm{ml}$ Eppendorf tube. Disodium EDTA $(2.5 \mathrm{mg})$ was used as anticoagulant. The samples were then maintained at $4^{\circ} \mathrm{C}$ for subsequent procedures. The total radioactivity in each total blood sample was counted. The samples were then centrifuged at $4^{\circ} \mathrm{C}$ at $2200 \times \mathrm{g}$. Radioactivity of the serum and pellet measured and about $50 \%$ of the total radioactivity was retained in the pellet. The serum was transferred to a $1.5 \mathrm{ml}$ Eppendorf tube containing about $700 \mathrm{ml}$ of $60 \%$ acetonitrile in water and centrifuged again to precipitate any residual proteins. The supernatant was analyzed using HPLC and examined for metabolites. HPLC was carried out 
on a C-18 Shimadzu $4.6 \times 250 \mathrm{~mm}$ HPLC column and eluted under gradient conditions $80 \% \mathrm{~A}$

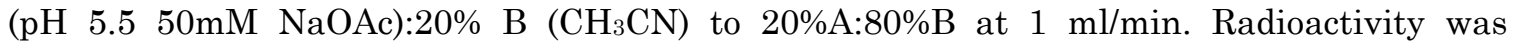
detected using Packard Radiomatic FLO-One / beta detector equipped with a PET flow cell containing BGO (bismuthgermanate) windows. Under these conditions we observed three radioactive peaks at 4.4, 15.1 and 16.9 minutes (Table S2). The peak at 16.9 min corresponds to $\left[{ }^{18} \mathrm{~F}\right]-5$ whereas the other two are metabolites.

Table S2. Metabolic profile of $\left[{ }^{18} \mathrm{~F}\right]-5$

\begin{tabular}{|c|c|c|c|}
\hline Time (min) & \multicolumn{3}{|c|}{ Peak (\% Radioactivity) } \\
\hline & $\begin{array}{c}1 \\
(4.4 \mathrm{~min})\end{array}$ & $\begin{array}{c}2 \\
(15.1 \mathrm{~min})\end{array}$ & $\begin{array}{c}3 \\
{\left[{ }^{18} \mathrm{~F}\right]-5} \\
(16.9 \mathrm{~min})\end{array}$ \\
\hline 30 & $58 \pm 19$ & $10 \pm 9$ & $31 \pm 11$ \\
\hline 60 & $88 \pm 4$ & $3 \pm 3$ & $9 \pm 3$ \\
\hline $120^{\dagger}$ & 84 & 7 & 8 \\
\hline
\end{tabular}

\section{Animal Imaging with PET.}

All animal studies were carried out within the framework of an institutional IACUC approved protocol (No. 86-02-020). Athymic nu/nu mice (National Cancer Institute, Bethesda, Maryland) were inoculated subcutaneously onto the right shoulder with $1 \times 10^{7}$ K562 cells mixed with Matrigel (BD Biosciences, San Jose, CA). K562 is a chronic myelogenous leukemia cell line cultured with IMDM (Iscove's modified Dulbecco's medium; prepared in-house) containing $4 \mathrm{mM} \mathrm{L}$-glutamine, $1.5 \mathrm{~g} / \mathrm{L}$ sodium bicarbonate, and $10 \%$ fetal bovine serum.

Three weeks following tumor inoculation, positron emission tomography (PET) images of mice were obtained using FOCUS 120 microPET $^{\mathrm{TM}}$ scanner (Siemens Preclinical Solutions, Knoxville, TN) with [18 $\mathrm{F}]-5$. Mice were injected intravenously (via tail vein) with $14 \pm 1 \mathrm{MBq}(375 \pm 25 \mathrm{\mu Ci})$ of $\left[{ }^{18} \mathrm{~F}\right]-5$ and imaged 60 minutes later under $2 \%$ (at $1 \mathrm{~L} / \mathrm{min}$ ) isoflurane anesthesia (Forane, Baxter Healthcare, Deerfield, IL). Image acquisition time was $15 \mathrm{~min}(\mathrm{t}=60$ to $75 \mathrm{~min})$ using a $250-750 \mathrm{keV}$ energy window and a $6 \mathrm{nsec}$ timing window. List-mode data were sorted into sinograms by Fourier re-binning and reconstructed by filter back-projection without attenuation correction. Count data in the reconstructed images were converted to activity concentration (i.e. \% of the injected dose per gram (\%ID/gm)) using a system calibration factor determined using a ${ }^{18 \mathrm{~F}}$-filled mouse-sized phantom. Visualization and analyses of microPET images were carried out using AsiPRO ${ }^{\text {TM }}$ software (Siemens Preclinical Solutions, Knoxville, TN).

\section{References.}

(1) It should be noted that 1-bromo-2-fluoroethane is now very difficult to procure in the USA. It is regulated as an EPA class I ozone-depleting substance. A suitable alternative for us has been 2-fluoroethyltriflate synthesized in situ from 2-fluoroethanol and triflic anhydride.

(2) Block, D.; Coenen, H. H.; Stocklin, G. The nca nucleophilic F-18 fluorination of 1,Ndisubstituted alkanes as fluoroalkylation agents. J. Labelled Comp. Radiopharm. 1987, 24, 1029-1042.

(3) Nagar, B.; Hantschel, O.; Young, M. A.; Scheffzek, K.; Veach, D.; Bornmann, V.; Clarkson, B.; Superti-Furga, G.; Kuriyan, J. Structural basis for the autoinhibition of c-Abl tyrosine kinase. Cell 2003, 112, 859-871.

(4) Tokarski, J. S.; Newitt, J. A.; Chang, C. Y. J.; Cheng, J. D.; Wittekind, M.; Kiefer, S. E.; Kish, K.; Lee, F. Y. F.; Borzillerri, R.; Lombardo, L. J.; Xie, D. L.; Zhang, Y. Q.; Klei, H. E. The structure of dasatinib (BMS-354825) bound to activated ABL kinase domain elucidates 
its inhibitory activity against imatinib-resistant ABL mutants. Cancer Res. 2006, 66, 57905797.

(5) Trentham, D. R.; Bardsley, R. G.; Ecclesto.Jf. Elementary processes of magnesium iondependent adenosine-triphosphatase activity of heavy meromyosin - transient kinetic approach to study of kinases and adenosine triphosphatases and a colorimetric inorganicphosphate assay in-situ. Biochem. J. 1972, 126, 635-644.

(6) Carter, T. A.; Wodicka, L. M.; Shah, N. P.; Velasco, A. M.; Fabian, M. A.; Treiber, D. K.; Milanov, Z. V.; Atteridge, C. E.; Biggs, W. H.; Edeen, P. T.; Floyd, M.; Ford, J. M.; Grotzfeld, R. M.; Herrgard, S.; Insko, D. E.; Mehta, S. A.; Patel, H. K.; Pao, W.; Sawyers, C. L.; Varmus, H.; Zarrinkar, P. P.; Lockhart, D. J. Inhibition of drug-resistant mutants of ABL, KIT, and EGF receptor kinases. P. Natl. Acad. Sci. USA 2005, 102, 11011-11016.

(7) Berman, E.; Jhanwar, S.; McBride, M.; Strife, A.; Wisniewski, D.; Lambek, C.; Clarkson, B. Characterization of two novel sublines established from a human megakaryoblastic leukemia cell line transfected with p210(BCR-ABL). Leukemia Res. 2000, 24, 289-297.

(8) Matsuguchi, T.; Salgia, R.; Hallek, M.; Eder, M.; Druker, B.; Ernst, T. J.; Griffin, J. D. Shc phosphorylation in myeloid cells is regulated by granulocyte-macrophage colonystimulating factor, interleukin-3, and steel factor and is constitutively increased by p210(bcr/abl). J. Biol. Chem. 1994, 269, 5016-5021. 